\title{
Performance and carcass characteristics of broiler chickens fed maize-cassava diets supplemented with methionine and inorganic sulphur
}

Oguntoye, M. A., Idowu, O. M. O. and Oso, A. O. Department of Animal Nutrition, College of Animal Science and Livestock Production Federal University of Agriculture, Abeokuta, Ogun State, Nigeria Abstract Corresponding author: ingenuityma@gmail.com

The major challenges of cassava supplementation in poultry diets are high cyanide and low protein content. This study was conducted to evaluate the nutritional value of maize-cassava diets supplemented with methionine and inorganic sulphur for broiler chickens. A total of 270 one day-old broiler chicks were randomly assigned to nine treatment groups of 30 birds with 10 birds per replicate. Starter and finisher diets were formulated and fed for a period of 56 days. Dietary treatments were subjected to completely randomized design. The birds were fed diets supplemented with 0, 125, $250 \mathrm{mg} / \mathrm{kg} \mathrm{DL-methionine} \mathrm{and} \mathrm{0,} \mathrm{125,} 250 \mathrm{mg} / \mathrm{kg}$ inorganic sulphur from $\mathrm{CuSO}_{4}$. There was a linear increase in final weight $(\mathrm{FW})$ and total weight gain (TWG) with supplementation of $125 \mathrm{mg} / \mathrm{kg}$ DL-methionine across dietary sulphur levels at the starter phase. Birds fed diets supplemented with $125 \mathrm{mg} / \mathrm{kg} \mathrm{DL-methionine} \mathrm{and} 250$ $\mathrm{mg} / \mathrm{kg}$ inorganic sulphur showed higher ( $p<0.05$ values of $463.23 \mathrm{~g}, 424.66 \mathrm{~g}$ and 2.66 for $\mathrm{FW}$, $T W G$ and feed conversion ratio respectively. The finisher phase followed a similar trend. Carcass yield showed significant $(p<0.05)$ improvement in dress weight, cut part and organ weight in birds fed diets supplemented with $125 \mathrm{mg} / \mathrm{kg} \mathrm{DL}$-methionine and $250 \mathrm{mg} / \mathrm{kg}$ inorganic sulphur. The findings revealed that birds with diets supplemented with $125 \mathrm{mg} / \mathrm{kg}$ DL-methionine and $250 \mathrm{mg} / \mathrm{kg}$ inorganic sulphur showed improved growth performance and carcass yield. In conclusion from this study supplementation of DL-methionine and inorganic sulphur in diets for broiler chickens resulted in improved growth performance and carcass yield.

Keywords: Maize-cassava, DL-Methionine, inorganic sulphur, broiler chicken

\section{Introduction}

Nigerian poultry farmers continue to experience a rise in cost of production as a result of the ever increasing cost of feeds. Prices of conventional energy sources in Nigeria for feeding chickens keep increasing. Among these energy sources, maize is the most widely used and its price in the market has been the most unpredictable. This is partly because it has so many alternative uses and its production has not been able to match up the daily demands for both man and livestock. Within the past three years, its price has fluctuated while those of unconventional feed sources like sweet potato remained virtually stable and cheap.

Maize is currently the most widely used grain crop for feeding poultry in Nigeria, occupying $40-60 \%$ as the conventional energy source for poultry. Its price keeps on rising to a level causing instability in the poultry industry and the prospect of increasing its production to magnitude that can satisfy its various uses is an illusion. There is therefore an urgent need to search for alternative energy sources if the collapse of poultry industry is to be averted. Nonconventional feedstuffs, according to Dafwang (2006) offer the best alternative in Nigeria for the reduction of feed cost and cost of animal products. Cassava root 


\section{Broiler chickens fed maize-cassava diets supplemented with methionine and inorganic sulphur}

contain highly digestible energy and are capable of providing high yield of energy per hectare just like maize (Hahn et al., 1992). Cassava contains the highest digestible energy (DE) among the root crops consisting of about $70-80 \%$ starch (Gomez, 1992). It is believed that through processing, its toxicity could be reduced to a tolerable level, thereby enhancing its usability as a replacement for maize.

Methionine has been shown to be the first limiting amino acid in broiler chickens diets and it is commonly used in commercial feeds (Ohta et al., 1993). Apart from the fact that it is an essential amino acid, it can also be converted to cystine in broiler chickens (Mendoca and Jensen, 1989). Methionine may also partly compensate for a deficiency of choline and vitamin $\mathrm{B}_{12}$ by providing the needed methyl group. Little attention has been paid to the importance of sulphur in animal nutrition since the intake of this element is mainly in the form of protein. Therefore, methionine and other sulphurcontaining amino-acids have been utilized as the main source of sulphur for other metabolic activities apart from their primary functions as amino acids. It has been realized, however, that the amount of sulphur present in the diet may be limiting factor for the synthesis of cystine, cysteine and methionine (Mcdonald et al., 1992). It is imperative to carry out research with a view to arrest high cost of livestock feed associated with increase in cost of maize as energy source. Cassava is readily available and can be an alternative for maize. However, cassava is of low crude protein compared to maize and this could be improved upon with supplementation of precursor such as amino acid and sulphur sources to aid biosynthesis of protein.

\section{Materials and methods Experimental site}

The research was carried out at the Poultry
Unit of the Directorate of University Farms, Federal University of Agriculture, Abeokuta. It lies within the forest vegetation zone of western Nigeria at latitude $7^{\circ} \mathrm{S} 13^{\prime} 49.46^{\prime} \mathrm{N}$, longitude $3^{\circ} 26^{\prime}$ $11.98^{\prime} \mathrm{E}$ with a mean annual rainfall of 1037 $\mathrm{mm}$ and average temperature of $34.7{ }^{\circ} \mathrm{C}$ (Google Earth, 2011).

\section{Experimental birds and management}

A total number of 270 day old unsexed broiler chicks of commercial strain (Marshal Broiler) were purchased from a reputable hatchery in Abeokuta. The chicks were weighed and allotted to nine dietary treatment groups of three replicates each in a completely randomized experimental design. Each replicate consisted of 10 chicks, to have a total of 30 per treatment group. The chicks were brooded for two weeks and then reared on deep litter housing system in two phases: starter phase (0-4 weeks) and finisher phase (5-8 weeks) respectively. Routine vaccinations and medications were strictly adhered to and feed and water were given ad libitum.

\section{Experimental diets}

The experimental diets were formulated for both starter and finisher phases to meet NRC (1994) minimum nutrient requirement. There were nine dietary treatments in a completely randomized design arranged in a $3 \times 3$ factorial arrangement of 3 levels of DL -methionine $(0,125$ and $250 \mathrm{mg} / \mathrm{kg})$ and inorganic sulphur supplementation $(0,125$ and 250 $\mathrm{mg} / \mathrm{kg})$. The dietary treatments include: $0 \mathrm{mg} / \mathrm{kg}$ DL-methionine $+0 \mathrm{mg} / \mathrm{kg}$ copper sulphate (T1),0mg/kg DL-methionine + $125 \mathrm{mg} / \mathrm{kg}$ copper sulphate (T2),0mg/kg DL-methionine $+250 \mathrm{mg} / \mathrm{kg}$ copper sulphate (T3), $125 \mathrm{mg} / \mathrm{kg}$ DL-methionine + $0 \mathrm{mg} / \mathrm{kg}$ copper sulphate (T4),125mg/kg DL-methionine $+125 \mathrm{mg} / \mathrm{kg}$ copper sulphate (T5),125mg/kg DL-methionine + $250 \mathrm{mg} / \mathrm{kg}$ copper sulphate (T6),250mg/kg DL-methionine $+0 \mathrm{mg} / \mathrm{kg}$ copper sulphate 
Oguntoye, Idowu and Oso

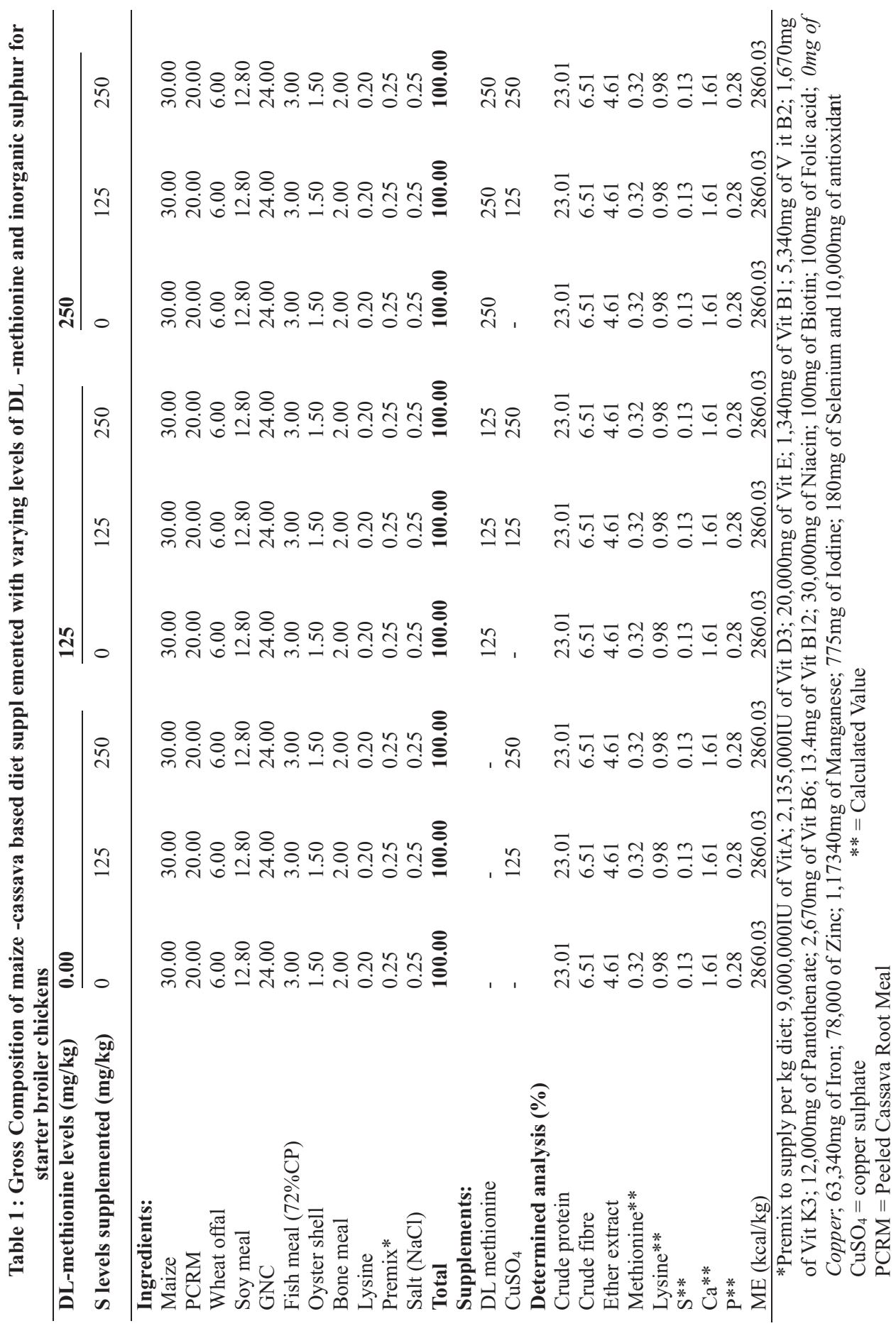


Broiler chickens fed maize-cassava diets supplemented with methionine and inorganic sulphur

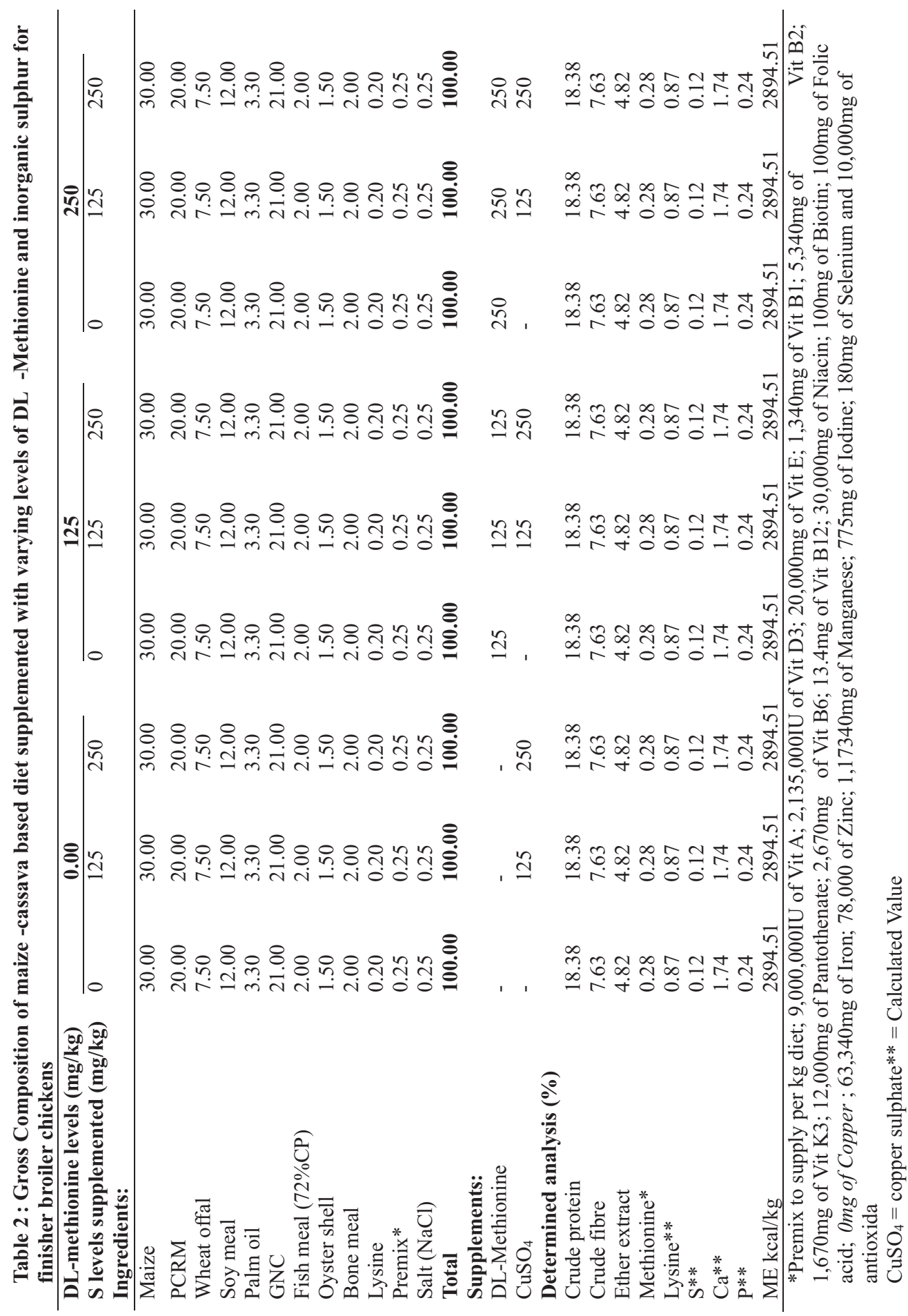




\section{Oguntoye, Idowu and Oso}

(T7), $250 \mathrm{mg} / \mathrm{kg}$ DL-methionine + $125 \mathrm{mg} / \mathrm{kg}$ copper sulphate (T8) and $250 \mathrm{mg} / \mathrm{kg}$ DL-methionine $+250 \mathrm{mg} / \mathrm{kg}$ copper sulphate (T9).

\section{Sources of ingredients and preparation}

The freshly harvested cassava tubers were obtained from Alabata village in Abeokuta. The tubers were cleaned and washed free from soil particles, peeled and chopped into small sizes $(0.5 \mathrm{~cm})$. They were spread on a concrete floor for 4 days to dry, packed and stored until time of use. DL -Methionine was supplied by Adisseo USA Incorporation. North Point Parkway. Alpharetta GA 30022 USA while the copper sulphate pentahydrate $\left(\mathrm{CuSO}_{4} \cdot 5 \mathrm{H}_{2} \mathrm{O}\right)$ was obtained from Sigma Chemical Company (St. Louis, USA).

\section{Data Collection}

\section{Performance characteristics}

The initial weights of the birds were taken on arrival. The live weights of the birds as well as the feed consumption were measured weekly. Feed conversion ratio for each replicate was determined by dividing the feed intake by the weight gain.

Average body weight $=$

Final body weight $(\mathrm{g})$ - Initial body weight

$$
\text { Number of birds }
$$

Feed conversion ratio $=$

Total feed intake $(\mathrm{g})$

Body weight gain $(\mathrm{g})$

Mortality $=$ Number of dead birds $\times 100$

\section{Carcass evaluation}

$$
\text { Initial number of birds }
$$

At the end of the experiment, two birds per replicate were selected. Prior to slaughtering, the birds were starved but had access to clean water for 12 hours to clear gut content. The slaughtered birds were allowed to bleed thoroughly, feathers were plucked and eviscerated. The weight of the cut-up parts (thighs, drum sticks, breast, back, wings, head, neck and shanks), organs (gizzards, liver, lungs and kidney) were determined using sensitive scale (top loading).

\section{Statistical analysis}

Data obtained were subjected to analyses of variance. Significant $(\mathrm{P}<0.05)$ means among variables were separated using Duncan Multiple Range F-test as contained in SAS (1999) package.

\section{Experimental model}

$\mathrm{Y}_{\mathrm{ijk}}=\mu+\mathrm{A}_{\mathrm{i}}+\mathrm{B}_{\mathrm{j}}+(\mathrm{AB})_{\mathrm{ij}}+\mathrm{E}_{\mathrm{ijk}}$

$\mathrm{Y}_{\mathrm{ijk}}=$ Individual observation

$\mu=$ Population mean

$A_{i}=$ main effect of varying levels of DLMethionine

$B_{j}=$ main effect of varying levels of inorganic sulphur

$(A B)_{i j}=$ effect of interaction of DL methionine and inorganic sulphur

$\mathrm{E}_{\mathrm{ijk}}=$ Experimental error

\section{Results}

Table 3 shows the performance characteristics of starter broiler chickens fed the varying levels of DL-methionine and sulphur. With the exception of feed intake, all parameters measured were significantly $(\mathrm{P}<0.05)$ affected by dietary treatments. Birds fed diets supplemented with $125 \mathrm{mg} / \mathrm{kg}$ DL-methionine showed increased values for final weight and total weight gain with increasing level of inorganic sulphur sourced from $\mathrm{CuSO}_{4}$. Higher significant $(\mathrm{P}<0.05)$ values of $463.23 \mathrm{~g}, 424.66 \mathrm{~g}$ and $15.17 \mathrm{~g}$ were obtained for final weight, total weight gain and weight gain $/ \mathrm{b} / \mathrm{d}$ in the birds fed diet supplemented with $125 \mathrm{mg} / \mathrm{kg}$ DLmethionine and $250 \mathrm{mg} / \mathrm{kg}$ inorganic sulphur sourced from $\mathrm{CuSO}_{4}$ compared to the control diet. Least value of 2.67 was obtained for feed conversion ratio in the birds fed with diet supplemented with 125 $\mathrm{mg} / \mathrm{kg}$ DL-methionine with $250 \mathrm{mg} / \mathrm{kg}$ inorganic sulphur sourced from $\mathrm{CuSO}_{4}$. The result of interaction effect of varying levels of DL-methionine and inorganic 
sulphur sourced from $\mathrm{CuSO}_{4}$ on growth performance of finisher broiler chickens is presented in Table 4. Final weight, total weight gain, weight gain/b/d and feed intake were significantly $(\mathrm{P}<0.05)$ influenced by dietary treatment. Higher significant $(\mathrm{P}<0.05)$ values of $2057.6 \mathrm{~g}$, $1612.88 \mathrm{~g}$ and $57.60 \mathrm{~g}$ were obtained for final weight, total weight gain and weight gain/b/d respectively in the birds fed diet supplemented with $125 \mathrm{mg} / \mathrm{kg}$ DLmethionine and $250 \mathrm{mg} / \mathrm{kg}$ inorganic sulphur sourced from $\mathrm{CuSO}_{4}$ compared to birds on Control diet. Lowest value of $148.78 \mathrm{~g}$ was obtained for feed intake in birds fed diet containing $125 \mathrm{mg} / \mathrm{kg}$ DLmethionine and $125 \mathrm{mg} / \mathrm{kg}$ inorganic sulphur sourced from $\mathrm{CuSO}_{4}$. Feed conversion ratio and mortality were not significantly $(\mathrm{P}>0.05)$ influenced by combination of DL-methionine and inorganic sulphur sourced from $\mathrm{CuSO}_{4}$. The Effect of varying levels of DL-methionine and inorganic sulphur on carcass characteristics of broiler chickens is presented in Table 5. With the exception of head, lung, kidney and spleen all parameters were significantly $(\mathrm{P}<0.05)$ influenced by dietary treatments. Highest significant $(\mathrm{P}<0.05)$ value of $2091.97 \mathrm{~g}, 1967.12 \mathrm{~g}$, $1588.52 \mathrm{~g}, 10.51 \%, 4.42 \%$ and $10.84 \%$ were obtained for live weight, plucked weight, eviscerated weight thigh, neck and drumstick respectively in birds fed with diet supplemented with $125 \mathrm{mg} / \mathrm{kg}$ DLmethionine with $250 \mathrm{mg} / \mathrm{kg}$ inorganic sulphur sourced from $\mathrm{CuSO}_{4}$. With the exception of breast, drumstick and abdominal fat values obtained for diet supplemented with $125 \mathrm{mg} / \mathrm{kg}$ DLmethionine increased with increasing level of inorganic sulphur sourced from $\mathrm{CuSO}_{4}$. Values obtained for wing, back, neck, lung, heart and intestine increased with increasing level of inorganic sulphur sourced from $\mathrm{CuSO}_{4}$ in the diet supplemented with $0 \mathrm{mg} / \mathrm{kg}$ DLmethionine. With the exception of live weight, breast and intestine similar values were recorded for parameters measured in the diet supplemented with $250 \mathrm{mg} / \mathrm{kg}$ DLmethionine irrespective of levels of inorganic sulphur sourced from $\mathrm{CuSO}_{4}$.

\section{Discussion}

Improved final weight, total weight gain, weight gain/b/d and feed conversion ratio were observed at starter phase of the birds in the first experiment where DL-methionine and inorganic sulphur sourced were supplemented. Significant improvement in weight gain with increasing methionine level could be attributed to ability of methionine in enhancing biosynthesis of protein for tissue build up. Improvement in weight gain with increasing methionine level was reported by Wang et al.(2004). Superior performance in body weight gain and feed conversion ratio in birds fed with methionine supplemented diets either synthetic or herbal was reported by (Halder and Roy, 2007). Also, Garlick (1985) reported an improvement in feed conversion ratio (FCR) at starter phase when broiler chickens were fed diet supplemented with DL-methionine. However, in contrary to the findings in the present study, Wang et al. (2004) reported that supplementation of DL-methionine did not result to improved FCR. The improvement in final weight, total weight gain, weight gain/b/d, feed conversion ratio and mortality achieved at the starter phase of this study following increased dietary inorganic sulphur could be due to ability of copper sulphate to stimulate enzymes involved in nutrient digestion and utilization. Significant improvement in weight gain and feed conversion ratio has been reported when broilers were fed diets supplemented with $125-250 \mathrm{mg} / \mathrm{kg} \mathrm{Cu}$ 


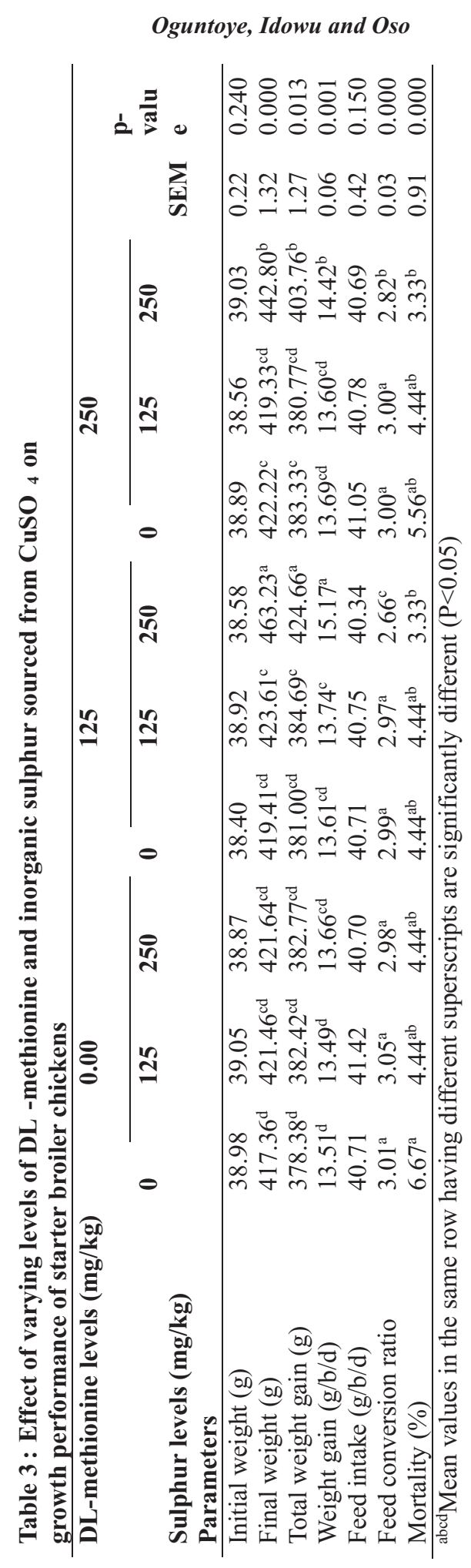




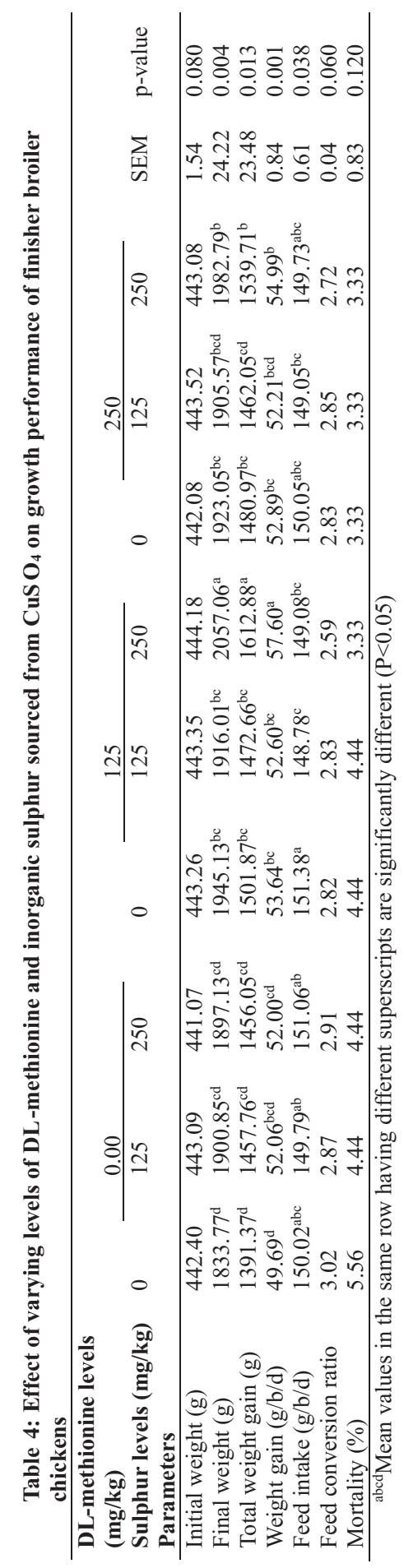


Oguntoye, Idowu and Oso

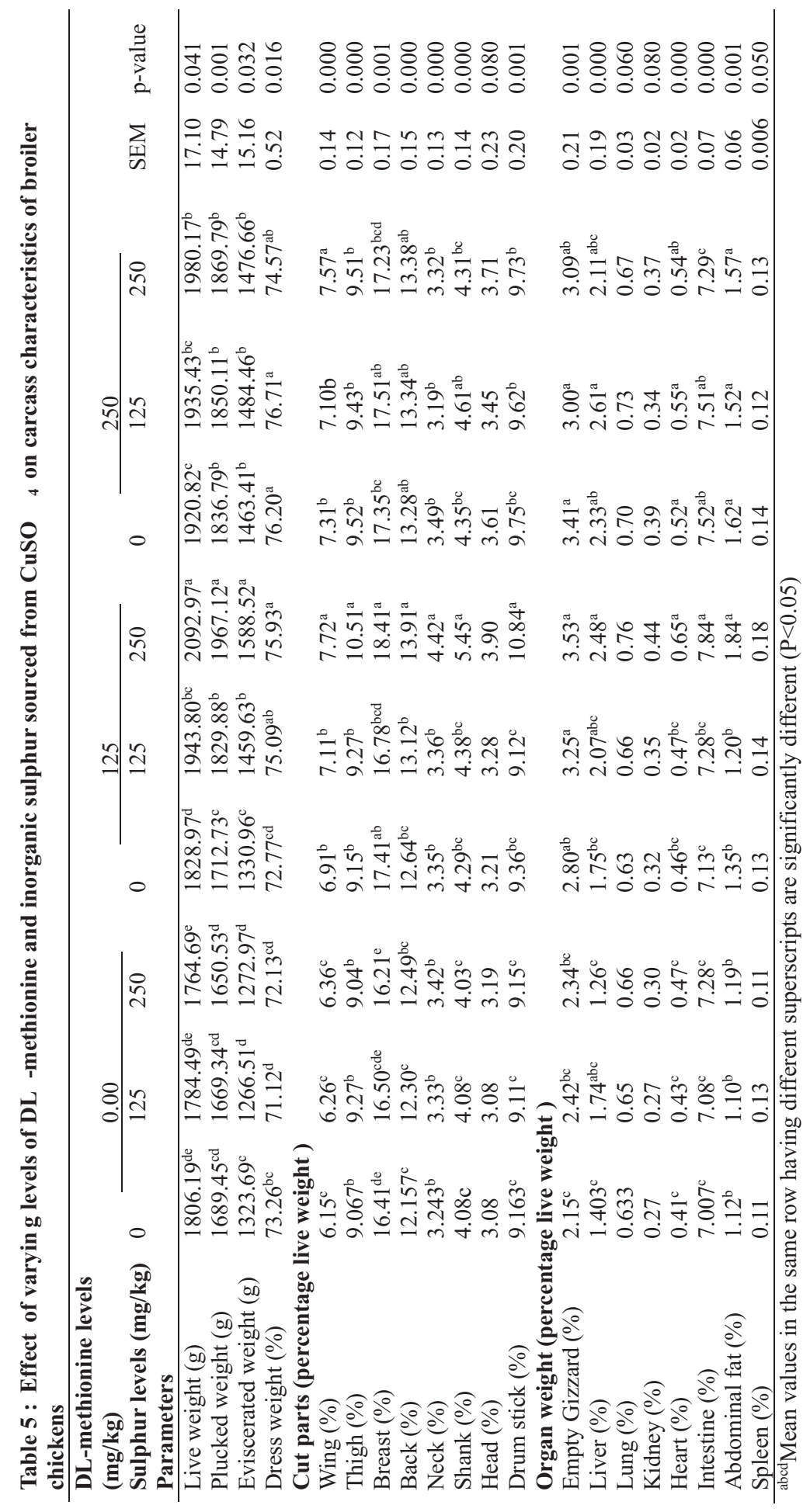




\section{Broiler chickens fed maize-cassava diets supplemented with methionine and inorganic sulphur}

inform of sulphate (Choi and Paik, 1989; Baker et al., 1991).

Higher significant values obtained for final weight, total weight gain and weight gain/b/d in birds fed diet supplemented with $125 \mathrm{mg} / \mathrm{kg}$ DL-methionine and 250 $\mathrm{mg} / \mathrm{kg}$ inorganic sulphur could be associated with better utilization of the diet. This implied that the birds on diet supplemented with $125 \mathrm{mg} / \mathrm{kg}$ DLmethionine with $250 \mathrm{mg} / \mathrm{kg}$ inorganic sulphur showed better growth response compared to those in other diets. Performance at the finisher phase of broiler chickens fed diet supplemented with DL methionine followed the same trend with starter phase. The improved final weight and weight gain for finisher birds fed diet supplemented with inorganic sulphur sourced from $\mathrm{CuSO}_{4}$ confirm the growth stimulating effect of copper sulphate. Increased feed intake has been observed in many studies involving copper sulphate supplementation in poultry diets for growth performance (Edmonds et al., 1985; Coffey et al., 1994).

In the present study, improvement was observed in carcass yield with DLmethionine supplementation. Higher values obtained for live weight, plucked weight, eviscerated weight, dressed weight, cut parts and organs with increasing level of DL-methionine in this study could be associated to efficient utilization of the diet. Improved weight gain with increasing methionine level was reported by Garlick (1985). Also, Meirelles et al. (2003) reported improved weight gain with high level of DL-methionine. This study agreed with findings of Chattopadhyay et al. (2006) who reported improved dressing percent, thigh and breast yield in broilers with DL-methionine supplementation at rate of $15 \mathrm{~g} / \mathrm{kg}$. Thigh and breast which are usually the consumer's preference increased with DL-methionine supplementation. This finding supported the work of Ojano-Birain and Waldroup (2002) who observed significant improvement in dressing percentage and breast meat yield when broilers were fed supplemental DL-methionine higher than NRC recommended level. More recently, the sensitivity of breast meat in broiler to dietary methionine has repeatedly been demonstrated (Huyghebaert et al., 1994; Schutte and Pack, 1995). Zhang et al. (2009) found that carcass weight of 45 day old chicken fed $188 \mathrm{mg} / \mathrm{kg} \mathrm{Cu}$ were heavier than when chickens were fed diet containing $8 \mathrm{mg} / \mathrm{kg} \mathrm{Cu}$. In the same vein, the author reported that the eviscerated yield of broiler chicken fed diet containing $50 \mathrm{mg} / \mathrm{kg} \mathrm{Cu}$ was higher than that of broilers fed with control diet. Interaction effect of DLmethionine and inorganic sulphur sourced from $\mathrm{CuSO}_{4}$ showed an improvement in this study. Higher values obtained for carcass parameters in birds fed diet supplemented with $125 \mathrm{mg} / \mathrm{kg}$ DL-methionine and 250 $\mathrm{mg} / \mathrm{kg}$ inorganic sulphur could be associated with better absorption of the nutrient. Paik et al. (1999) reported that $\mathrm{Cu}$ from a $\mathrm{Cu}$-methionine complex was better absorbed and accumulated to a higher degree in breast muscle and to a lower degree in the liver of chicken than $\mathrm{Cu}$ from inorganic sulphur.

\section{Conclusion}

The study showed that supplementation of $125 \mathrm{mg} / \mathrm{kg}$ DL-methionine with $250 \mathrm{mg} / \mathrm{kg}$ inorganic sulphur sourced from $\mathrm{CuSO}_{4}$ improved growth performance in broiler chickens at the starter and finisher phases. Supplementation of $125 \mathrm{mg} / \mathrm{kg}$ DLmethionine and $250 \mathrm{mg} / \mathrm{kg}$ inorganic sulphur indicated improved carcass yield.

\section{References}

Baker, D. H., Odle, J., Funk, M. A. and 
Wieland, T. M. 1991. Research note: bioavailability of copper in cupric oxide, cuprous oxide and in copper lysine complex. Poultry Science. 70, 177-179.

Chattopadhyay, K., Mondel, M. K. and Roy, B. 2006. Comparative Efficacy of DL-methionine and Herbal methionine on performance of broiler chicken.International Journal of Poultry Science 5(11): $1034-1039$.

Choi, Y. J. and Paik, I. K. 1989. The Effect of Supplementing copper sulphate on the performance of broiler chicken. Korean Journal of Animal Nutrition and Feeding: 13: 193-200.

Coffey, R. D., Cromwell, G. L. and Monegue, H. J. 1994. Ef? cacy of a copper-lysine complex as a growth promotant for weaning pigs.Journal of Animal Science. 72: 2880-2886.

D'Mello, J. P. F. 1993.Amino acid supplementation of cereal-based diets for non-ruminants, Animal. Feed Science. Technol.45: 1-18

Dafwang, I. I. 2006. The replacement value of blood meal for fish meal in rations for poultry raised in the tropics, M. Sc. ThesisAhmadu Bello University, Zaria, Nigeria.

Edmonds, J. S., Izquiendo, O. A. and Baker, D. H. 1985. Feed additive studies with newly weaned pigs: Efficacy of supplemental copper, antibiotics and organic acids. Journal of Animal Science. 60:462479.

Garlick, J. D. 1985. Response of broiler to DL-methionine hydroxy analoguefree acid, DL-methionineand Lmethionine. Poultry Science. 64: 1541-1584.

Gomez, T. M., Motarjemi, Y., Miyagewa,
S., Kaferstein, F. K. and Stohr, K. 1992. Food borne salmonellosis. World Health 50:81 -89.

Hahn, S. K., Reynolds, L. and Egbunike, G. N. 1992. Cassava as livestock feed in Africa proceeding of the IITA/ILCA University of Ibadan. Workshop on the potential utilization of cassava as livestock in Africa.

Halder, G. and Roy, B. 2007. Effect of Herbal or synthetic methionine on performance, Cost Benefit Ratio, Meat and Feather Quality of Broiler Chicken. International Journal of Agricultural Research; 2: 987-996.

Huyghebaert, G., Pack, M. and Groote, G. 1994. Influence of protein concentration on the response of broilers tosupplemental DLmethionine. Arch. Geflu" gelkd. 58:23-29.

Meirelles, H. T., Albuquerque, R., Borgatti, L. M. O., Souza, L. W. O., Meister, N. C. and Lima, F. R. 2003.Performance of broilers fed with different levels of methionine hydroxy analogue and DL$\mathrm{m}$ e $\mathrm{t} h$ i $\mathrm{o} \quad \mathrm{n}$ i $\mathrm{n}$ e. JournalPoultryScience. 5: 69-74.

Mendoca, C. X. J. R. and Jensen, L. S. 1989. Influence of valine level on performance of older broilers fed low protein diet supplemented with amino acids, Journal of Animal Nutrition and Feeding40:427-452.

N.R.C. 1994. Nutritional Research Council Nutrient Requirement of poultry $9^{\text {th }}$ edn. Revised edition National Academy of Science. Washington D.C.

Nwokoro, S. O. 1991.Methionine and lysine requirements of cockerels in lowland humid tropics, Ph.D. 
Broiler chickens fed maize-cassava diets supplemented with methionine and inorganic sulphur

thesis, Department of Animal Science, University of Ibadan, Nigeria.

Obioha, F. C. 1992.A Guide to Poultry Production in the Tropics, 1st edn, Accia Publishers, Nigeria. pp. 4779.

Ohta, T., Toyomizu, M. and Ishibashi, T. 1993. Comparison of the effect of supplementation of methionine and cystine on performance and abdominal fat of broilers, Proceedings, World Conference on Animal Production, Canada, pp. 112-113.

Ojano-Dirain, C. P. and Waldroup, P. W. 2002. Evaluation of lysine, methionine and threonine needs ofbroilers three to six weeks of age under moderatetemperature stress. International Journal ofPoultryScience. 1: 16-21.

Okafor, N. 1992. Commercialization of fermented foods in the sub Saharan Africa. In: Application of Bacteriology to Traditional fermented food. $2^{\text {nd }}$ edition. John Wale and sons, Nigeria. pp. 165169.

Paik, I. K., Seo, S. H., Um, J. S., Chang, M. B., Lee, B. H. 1999. Effects of supplementary copper-chelate on the performance and cholesterol level in plasma and breast muscle of broiler chickens. Asian -
Australian. Journal of AnimalScience. 12: 794-798.

SAS, 1999. Version 8, SAS. Institute Inc., carry NC., USA.

Schutte, J. B. and Pack, M. 1995.Sulphur amino acid requirement of broiler chicks from fourteen to thirty eight days of age on performance and carcass yield. PoultryScience. 74: 480-487.

Tewe, O. O. and Kasali, O. B. 1986. Effect of cassava peel processing on the performance, nutrient utilization and physiopathology of the African giant rat (cricetomygambianus, water house).Tropical Agriculture (Trinidad) 63: 125-128.

Tewe, O. O., Aderemi, F. A., Oguntimehin, G. B., 1987. Processing andutilization of cassava roots in diets for layers IITA tropical rootsand tuber crops. Bulletin 9(2), 9-12.

Wang, Y. Z., Xu, Z. R. and Feng, J. 2004. The effect of betaine and DLmethionine on growth performance and carcass characteristics in meat ducks. Animal Feed Science. Tec., 116: 151-159.

Zhang, X. Q., Zhang, K. Y., Ding, X. M. and Bai, S. P. 2009. Effects of dietary supplementation with copper sulfate or tribasic copper chloride on carcass characteristics, tissue nutrients deposition and oxidation in broilersPakistan Journal of Nutrition. 8: 1114-1119.

Received: $25^{\text {th }}$ August, 2016 Accepted: $12^{\text {th }}$ March, 2017 